\title{
Corporate Social Responsibility Reporting Practices in Bangladesh: A Study of Selected Private Commercial Banks
}

\author{
Md. Abdul Kaium Masud ${ }^{1}$ Mohammad Sharif Hossain ${ }^{2}$ \\ ${ }^{1}$ (Lecturer, Dept. of Business Administration, Noakhali Science and Technology University, Bangladesh -3814 \\ ${ }^{2}$ (Lecturer in Accounting, Dept. of Business Administration, Uttara University, Bangladesh,
}

\begin{abstract}
Corporate Social Responsibility (CSR) reporting was a matter of developed countries. Now in the age of information CSR reporting plays a vital role in the developing countries like Bangladesh. Globalization made CSR reporting practices an imperative for Bangladesh Business. The paper tries to find out CSR reporting practices of selected Banks in consideration of finance act 2010 and 2011. The study was based on annual report of 2010 of listed Banks. The study revealed that 100\% Banks reported their CSR activities but it is also a matter of concern that less than 60\% Banks participated in prescribe CSR areas according to finance act.

Field of Research: Corporate Social Responsibility, Reporting, Bank, Finance Act.
\end{abstract}

\section{Introduction}

Corporate Social Responsibility is not only an act for humanity but also to provide good working environment to an organization's employees, to pay just remuneration, to give regular leave, to care as a human beings and to care environment of the society (The Daily Prothom-Alo). Business organizations in the society are accountable to implement different socially desirable activities not only for stakeholders concern but also for different external parties. CSR reporting can be a significant part in the financial reporting while it provides information to different stakeholders (Weygant et.al 2011) and as an additional part social report would provide information relating to whole environmental concern to society. The system of providing information may vary from company to company, country to country (Azim et al. 2011) but the common media of providing information is financial statement. However, there does not exist a universally accepted theoretical framework for corporate social and environmental reporting (Choi J.S 1999).

Corporate social responsibility is not the only ethical dilemma that financial institutions face in an atmosphere of corrupt corporate practice (Azim et al. 2011) but also these institutions are concerned with commitment for sustainable development but execution of such development procedural function's through compliance with CSR guidelines is difficult. Currently in Bangladesh, CSR is a matter of self-interest for the corporate sector (Azim et.al 2009). There is a crying need for an in-depth study into the quality, quantity of corporate social disclosure and identification of areas for future improvement so that transparency can be ensured.

Corporate Social Responsibility (CSR) reporting focuses vary by business, by size, by sector and even by geographic region. The area of CSR reporting is quite big and it includes all the good practices that increase the business profitability and can preserve interest of all stakeholders. Bangladesh is a developing country and thus compared to global competitiveness and demand, the CSR practices and standards are being implemented in Bangladesh (Alimullah, 2006) poorly. We are yet go a long way and is still lagging behind. For better and enhanced performance CSR rules and reporting implementation is thus now need, not merely demand. The study has taken an attempt to observe the CSR reporting practices of Private Commercial Banks in Bangladesh in consideration with finance act 2010 and 2011.

\section{Definition of CSR}

\section{Literatures Review}

CSR is a concept whereby financial institutions not only consider their profitability and growth, but also the interests of society and the environment by taking responsibility for the impact of their activities on stakeholders, employees, shareholders, customers, suppliers and civil society represented by NGOs (Noyer 2008).the process of communicating the social and environmental effects of organizations' economic actions to particular interest groups within society and to society at large (Gray et al. 1987, p. ix).

In a comparative study on 150 companies in the US, UK and Australia, Guthrie and Parker (1990) found that $85 \%$ of US, $98 \%$ of UK, and $56 \%$ of Australian companies made some social disclosures in their annual reports. This study indicated that more than $40 \%$ of these companies reported human resource issues, $31 \%$ reported community involvement, $13 \%$ reported environmental activities, and $7 \%$ reported energy and product related issues. It also revealed the average number of pages that organizations in these countries allotted 
in their reports for social disclosures. Companies in the US used 1.26 pages while 0.89 and 0.70 pages were used in the UK and Australia respectively.

Alam Shafiul, et al. (2010) pointed out that CSR is still an evolving concept that enables corporate executives to create and apply self-determined policies to best meet the needs and demands of its stakeholders. Here, it has remarked that the peculiar nature of CSR practices makes their cross-border management difficult. Achieving consistent CSR practices across global operations involves not only the transfer of the CSR practice, but also the transfer of its underlying value and meaning.

Azim et al. (2011) mentioned corporate social responsibility is not the only ethical dilemma that financial institutions face in an atmosphere of corrupt corporate practice. These institutions are also concerned with commitment for sustainable development. A well-functioning finance sector in any country can contribute directly to a healthy economy. Also cited, that CSR reporting of financial sector in Bangladesh is increasing and organization are concerned about the matter and significantly maintained in the annual report.

Belal A R (2001) made a study on different listed companies of Dhaka Stock Exchange (DSE) and found out that most of the companies made mandatory and non mandatory information. He also noted that $51 \%$ companies did not disclose mandatory information. He has taken the study in the context of politics \& history, economic, socio-culture and regulatory \& institutional. Lastly, he made a comment that a number of companies are making social disclosure but the quantity of information disclosed is very low.

Khan $\mathrm{H}$ et al. (2010) stated in their report that most of the banks in the Bangladesh are not aware of CSR reporting and there is no such study has been taken to give strict result on the matter. They also showed that the practices of CSR reporting are increasing day by day in other regions like Europe, Asia, North America and Latin America.

\section{Objectives}

Objectives of the studies are to examine current status of prevailing laws/rules and how far these are being implemented and reported in the annual report of Private Commercial Banks in Bangladesh (PCB).

\section{Methodology, Sample and data collection}

The study is exclusively a descriptive research on corporate social reporting practices of Private commercial banks in Bangladesh based on a small sample size. Thus, the study is purely based on the information from secondary data sources. The data collected for the purpose of the study involves the examination of annual reports for the year 2010 of selected private commercial banks.

In order to understand CSR disclosure by banking companies, annual reports are considered appropriate documents for analysis. Annual reports are a common and popular means of communication to stakeholders and they command the actual situation of the company. To analyze the extent of social responsibility reporting by Bangladeshi Banking companies, annual reports constituted the main primary source. Guthrie and Parker (1990), Gray, Owen and Adams (1996), Deegan and Rankin (1997) and other scholars studied corporate social reporting practices using annual reports as the key source of information. Additionally, it is documented that annual report is the most widespread and accepted document for corporate communication with different parties in Bangladesh.

\subsection{The Sample:}

The sample for the study has been taken from the listed private commercial bank's of the Dhaka Stock Exchange (DSE). The banking companies considered in the study include ten listed private commercial banks. The samples of ten commercial banks are Dutch Bangla Bank Ltd, Mercantile Bank Ltd, Prime Bank Ltd, Southeast bank Ltd, Eastern Bank Ltd, National Bank, Bank Asia Ltd., Dhaka Bank Ltd, City Bank Ltd and BRAC Bank Ltd.

In the study judgment sample has been used for choosing ten banks. Listed banking companies only considered for the study (10 out of 30) http://www.dsebd.org. For descriptive studies, a minimum acceptable size depending on the type of research is considered to be ten (10) percent of the population (Belal A.R 2001). Therefore, the sample size for the study is acceptable (33 percent).

\subsection{The Research Method:}

The research method of the study involved examination, verifying and analysis of the annual reports of selected Private Commercial Banks (PCB) to observe the practices of CSR reporting in touch the above research objectives. Content analysis has been widely used for CSR studies and the study has also taken an attempt to observe CSR reporting of PCBs by using content analysis. The Study has divided different CSR activities of PCBs into five major areas a) Education b) Health c) Environment \& Disaster d) Culture \& Sport e) Miscellaneous. 
The above five major areas have been used to show PCBs CSR practices with the prevailing finance act 2011. The study has taken an attempted to verify with the finance act 2011, prescribed 25 areas of CSR expenditures with $10 \mathrm{PCBs}$ annual report CSR disclosures.

\section{CSR Reporting Practices of Selected Banks}

Table 1: Area wise CSR activities of selected banks

\begin{tabular}{|c|c|c|c|c|}
\hline Education & Health & $\begin{array}{l}\text { Environment \& } \\
\text { Disaster }\end{array}$ & Culture \& Sport & Miscellaneous \\
\hline $\begin{array}{l}\text { Dutch Bangla } \\
\text { Mercantile Bank } \\
\text { Prime Bank } \\
\text { Southeast Bank } \\
\text { Eastern Bank } \\
\text { National Bank Bank } \\
\text { Asia } \\
\text { Dhaka Bank } \\
\text { City Bank } \\
\text { BRAC Bank }\end{array}$ & $\begin{array}{l}\text { Dutch Bangla } \\
\text { Mercantile Bank } \\
\text { Prime Bank } \\
\text { Southeast Bank } \\
\text { Eastern Bank } \\
\text { National Bank Bank } \\
\text { Asia } \\
\text { Dhaka Bank } \\
\text { City Bank }\end{array}$ & $\begin{array}{l}\text { Dutch Bangla } \\
\text { Mercantile Bank } \\
\text { Prime Bank } \\
\text { Southeast Bank } \\
\text { Eastern Bank } \\
\text { National Bank Bank. } \\
\text { Asia } \\
\text { Dhaka Bank } \\
\text { City Bank }\end{array}$ & $\begin{array}{l}\text { Dutch Bangla } \\
\text { Mercantile Bank } \\
\text { Prime Bank } \\
\text { Southeast Bank } \\
\text { Eastern Bank } \\
\text { National Bank Bank } \\
\text { Asia } \\
\text { Dhaka Bank }\end{array}$ & $\begin{array}{l}\text { Dutch Bangla } \\
\text { Mercantile Bank } \\
\text { Prime Bank } \\
\text { Southeast Bank } \\
\text { Eastern Bank } \\
\text { National Bank Bank } \\
\text { Asia } \\
\text { Dhaka Bank } \\
\text { City Bank } \\
\text { BRAC Bank }\end{array}$ \\
\hline All Banks & Nine Banks & Nine Banks & Eight Banks & All Banks \\
\hline
\end{tabular}

Above are the areas where most of the banks have contributed CSR expenditure. Except BRAC bank and City Bank, all other banks have participated in major five areas of CSR expenditure. In the annual report, 2010 most of the banks have reported financial information about education, health, environment $\&$ disaster and sport \& culture.

Table 2: Selected PCBs CSR Disclosures

\begin{tabular}{|l|l|l|c|}
\hline Sector & $\begin{array}{l}\text { Number of selected } \\
\text { companies }\end{array}$ & $\begin{array}{l}\text { Companies making CSR } \\
\text { disclosures }\end{array}$ & $\begin{array}{c}\text { Result } \\
(\%)\end{array}$ \\
\hline Banking Companies & 10 & 10 & 100 \\
\hline
\end{tabular}

The table shows the CSR disclosure result of selected banks. The table indicates all sampled companies disclosed at least verbally about CSR reporting. As only one year and ten sample banks annual report have been examined, so with this result it is not reasonable to remark about the whole industry practices but the result $100 \%$ is satisfactory in comparing with a recent study (Azim et al. 2011) that in our financial sector $41 \%$ companies make CSR reporting. Now there is a qualitative change in CSR reporting in our financial sector like private commercial banks.

Finance Act 2011 has described, a corporate entity is given a tax rebate at the rate of $20 \%$ or 8 crore which one is lower of total income and prescribed 25 areas of CSR expenditures (Bala S.K and Bhowmik R.K 2010 and Bhowmik R.K \& Bala S.K . 2011). CSR expenditure areas are given below:

Table 3: Verifying of Regulatory areas of CSR

\begin{tabular}{|l|l|l|}
\hline SN & CSR areas & $\begin{array}{l}\text { No. of } \\
\text { Banks }\end{array}$ \\
\hline 1 & Engaged in clean water management & 0 \\
\hline 2 & Engaged in afforestation & 0 \\
\hline 3 & Beautifications of cities & 2 \\
\hline 4 & Waste management & 0 \\
\hline 5 & Natural calamities & 10 \\
\hline 6 & Old persons homes & 0 \\
\hline 7 & Mentally or physically handicapped & 10 \\
\hline 8 & Education of rootless children & 10 \\
\hline 9 & Accommodation for the slum dwellers & 0 \\
\hline 10 & Women's rights and anti-dowry practices & 0 \\
\hline 11 & Rehabilitation of orphan/rootless children & 10 \\
\hline 12 & $\begin{array}{l}\text { In research on independence war, regaining and expansion of the } \\
\text { consciousness of the independence war and the act of honorable living of the } \\
\text { freedom fighters }\end{array}$ & 7 \\
\hline 13 & $\begin{array}{l}\text { Health some sanitation in Chittagong Hill Tracts, char areas and areas } \\
\text { surrounding breaking up of bank of river }\end{array}$ & 0 \\
\hline
\end{tabular}




\begin{tabular}{|l|l|l|}
\hline 14 & Engaged in treating cleft lips, cataract, cancer, and leprosy & 4 \\
\hline 15 & Engaged in treating acid victims & 1 \\
\hline 16 & Hospitals engaged in providing free medical treatment to poor patients & 10 \\
\hline 17 & $\begin{array}{l}\text { Birth control products with a view to solving the population problem and to } \\
\text { conduct camps for voluntary sterilization }\end{array}$ & 0 \\
\hline 18 & Grants to Public Universities & 5 \\
\hline 19 & Technical and vocational education for meritorious poor students & 5 \\
\hline 20 & $\begin{array}{l}\text { Training on computer or information technology and in establishing } \\
\text { infrastructure or in purchasing educational materials for implementing } \\
\text { English education in public /private educational institutions (under Monthly } \\
\text { Pay Order or MPO) }\end{array}$ & 8 \\
\hline 21 & $\begin{array}{l}\text { Technical and vocational training to unskilled or semi-skilled labor for } \\
\text { export of human resources }\end{array}$ & 0 \\
\hline 22 & Sports and provision of training at national level & 8 \\
\hline 23 & Donation to national level institution set up in memory of the liberation war & N/A \\
\hline 24 & $\begin{array}{l}\text { Donation to national level institution set up in memory of Father of the } \\
\text { nation }\end{array}$ & N/A \\
\hline 25 & Donation to Prime Minister's Higher education fund & N/A \\
\hline
\end{tabular}

The table verifies with the prevailing finance act 2010 and 2011 and CSR expenditure of sample PCBs. It proves that PCBs are very selected in CSR areas. Their expenditure is limited to some areas like health, education, natural disaster, sport \& culture. At best ten (10) banks participates in 5 areas, eight (8) banks in 2 areas, seven (7) banks in one area and five (5) banks in two areas. All of the banks major participation were fives areas.

Table 4: Mode of Disclosing Information

\begin{tabular}{|l|l|l|l|}
\hline No & Mode of Information & $\begin{array}{l}\text { No. of Companies } \\
\text { Disclosing Information }\end{array}$ & $\begin{array}{l}\text { Result } \\
(\%)\end{array}$ \\
\hline 1 & Only Financial Information (Monetary) & 01 & 10 \\
\hline 2 & Only Non Financial Information (Non Monetary) & 03 & 30 \\
\hline 3 & $\begin{array}{l}\text { Financial \& Non Financial ( Monetary \& Non } \\
\text { Monetary) }\end{array}$ & 06 & 60 \\
\hline 4 & No Information ( Monetary \& Non Monetary) & 0 & 0 \\
\hline
\end{tabular}

Table 3 outlines the mode of disclosing information. The analysis revealed that $60 \%$ of disclosures generalized information both monetary and non-monetary in nature. $30 \%$ of companies used only monetary information. $10 \%$ of reports contained only non-monetary information, and not a single company who provided any information. Financial accounting generally considers monetary information. As a result, selected companies are in a good position where $70 \%$ companies provide financial information relating with CSR in their annual report. One example is shown below:

Contribution to different sectors in 2010 (taka in million) education 50.16, health 27.02, disaster 12.5, culture \& sports 5.00 and miscellaneous 30.75 (Dutch Bangla Bank Ltd)

Table 5: Top-level Management Concern of CSR

\begin{tabular}{|l|l|l|}
\hline Level of Management & No. Banks Reporting & $\begin{array}{l}\text { Result } \\
(\%)\end{array}$ \\
\hline Chairman's Message & 08 & 80 \\
\hline Managing Director's Message & 09 & 90 \\
\hline Only Chairman & 01 & 10 \\
\hline Only Managing Director's & 02 & 20 \\
\hline Both of Chairman \& Managing Director's & 07 & 70 \\
\hline Other's Message & 01 & 10 \\
\hline
\end{tabular}

\footnotetext{
* Not Applicable; because the study was based on 2010 annual report of selected Banks but these rules are prescribed in 2011 finance act.
} 
As shown in Table 4, the most common place for locating social responsibility disclosures are the Managing Director's message 90\%, while 80\% report used the Chairman's message in the annual report. 70\% companies use both Chairman \& Managing Director's message while only $10 \%$ companies used chairman message and 20\% company used managing director's message in the annual report. There is only one bank where another person (not Chairman \& Managing Director's) provides a message relating with CSR activities. One example is given below:

Not only that we have concentrated our activities on business growth but also we have kept ourselves involved in activities related to corporate social responsibility. (Chairman of National Bank Ltd)

Table 6: Separate Section Used for devoting CSR disclosures

\begin{tabular}{|l|l|l|}
\hline Sections & No. of Companies & Result (\%) \\
\hline In the Table of Content & 07 & $70 \%$ \\
\hline In a separate Section & 10 & $100 \%$ \\
\hline
\end{tabular}

The table presents the disclosing of CSR information in the annual reports of the banks. $70 \%$ bank used the description of CSR in the table of content where they specially mentioned corporate social responsibility with page numbers. On the other hand, every bank used a separate section to provide CSR information. But it varies from bank to banks some banks used a few pages on the other hand, some banks used a few lines to disclose their financial and non-financial information related to CSR activities. The picture of all banks revealed that PCBs are very aware of CSR reporting in the annual report.

Table 7: Preferences on CSR activities

\begin{tabular}{|l|l|l|}
\hline Level of Preference & No. of Companies & $\%$ \\
\hline More Preference & 06 & 60 \\
\hline Less Preference & 04 & 40 \\
\hline
\end{tabular}

The table indicates level of preference given to disclose CSR information in the annual report. It is highly satisfactory that $60 \%$ banks highly concentrated on the issue while they are disclosing much information along with all top level management thinking, using more sections on the CSR issues and their future plan for the next year. $40 \%$ banks' preference level is satisfactory but there is a gap between top-level management thinking and implementation of CSR issue in this regard. One example is given in this regard:

We firmly believe in the concept of corporate social responsibility whereby we integrate social and environmental concern into our business operation. We are highly active in the area of promoting education and poverty alleviation of the country. (Managing director of Southeast Bank Ltd.)

\section{Conclusion}

Corporate Social responsibility is the indispensible part of production of a company. CSR ambassador of Sweden said that CSR had four real significances- position against corruption, human rights, justice to the interest of employees and environment protection (The daily Prothom-alo, 2011). This is the concept of a developed country we are far behind in thinking. However, we can take forward to maintaining a sustainable development.

Different studies (Imam 2000, Sultana 09, Almona C P 2005, Jamali D and Mishak R. 2007, Kabir E 2003) detected that there is no framework for CSR reporting but now there is a legal framework for CSR areas. There are 25 areas of CSR expenditure. Nevertheless, not a single bank participated in all of the specified areas. Maximum participation is not more than $(55 \%)$ of areas. PCBs corporate social responsibility is limited to natural disaster, health, education, sports and miscellaneous activities. Moreover, banks are clearly ahead in disclosing information in the annual report. All sampled banks $(100 \%)$ disclosed their CSR activities in the annual report. The study finds out that provided information generalized both financial and non-financial. $70 \%$ disclosed information is financial in nature. Most of the sampled Banks top-level management is concerned about CSR activities and significantly, they informed the matter in their statement. All PCBs provided enough spaces for CSR activities in the annual report.

For standard financial reporting we need to develop a Bangladesh Accounting Standard (BAS) of CSR reporting and presentation. Banking Companies should participate in all prescribed areas of CSR to show their real contribution in the economic development of the country. Financial information should be trustworthy to all levels of interested users so all private banks should disclose CSR information both monetary and nonmonetary, they should give more and detailed information about corporate CSR expenditure. Government is not beyond responsibility. So it should take necessary steps to encourage private commercial banks to enhance their 
contribution in the matter. As a guardian of financial market, Bangladesh Bank should monitor the activities of banks corporate social responsibility and reporting.

In conclusion, it may be said that our private commercial banks corporate social responsibility reporting practice is developing day by day. They are trying to follow the rules of finance act. But their participation is not satisfactory in all areas. There are about $45 \%$ areas where no contribution. So they must think about the issue of areas. Private commercial banks have a great contribution in our economy so it's a self introductory matter of them to report corporate social responsibility information in the annual report to flourish their image in the society as well as to develop an accountable society. However, the conclusion is subject to certain limitations noted earlier and requires more sample and relevant data for further research.

\section{References}

[1] The Daily Prothom-alo, No. 12, November 18, 2011, Pp. 21

[2] Weygandt, J.J, Kimmel, P.D and Kieso, D.E 2009, "Intermediate Accounting" John Willy \& Sons,Inc, 2011

[3] Choi, John. Seo, An investigation of the initial voluntary environmental disclosures made in korean semi annual financial reports, Pacific Accounting Review, Vol. 11, No 1, June 1999

[4] Azim M, Ahmed E \& Netto DB , "Corporate Social Disclosure in Bangladesh: A Study of the Financial Sector" International Review of Business Research Papers, Vol. 7. No.2. March 2011, Pp.37-55

[5] Azim, MI, Ahmed S \& Islam, MS , "Corporate social reporting practice: evidence from listed companies in Bangladesh", Journal of Asia-Pacific Business, vol. 10, No. 2, 2009, Pp. 130-145

[6] Miyan M Alimullah , "Dynamics of Corporate Social Responsibility - Bangladesh Context" Journal of AIUB Bangladesh, August, Vol. 3, No. 1, 2006, Pp. 13-32

[7] Noyer, C 2008, viewed 15 October 2009, http://www.banque france.fr discourse/disc081028.pdf

[8] Gray R.H, Owen, D and Maunders, K, Corporate Social Reporting: Accounting and Accountability, Prentice-Hall International, London, 1987

[9] Alam S.M Shafiul et.al , "Corporate Social Responsibility of Multi National Corporations in Bangladesh: A Case study on Grameenphone", Journal of Patuakhali Science and Technology University, Vol. 02, no. 01, June 2010, Pp. 51-61

[10] Belal, A. R, “A study of corporate social disclosures in Bangladesh $\square$, Managerial Auditing Journal, vol. 16, 2001, Pp. $274-289$.

[11] Belal, A. R., and Owen, D. "The Views of Corporate Managers on the Current State of and Future Prospects for, Social Reporting in Bangladesh: An Engagement Based Study”, Accounting, Auditing \& Accountability Journal, Vol. 20 No.3, 2007 , Pp. 472-494.

[12] Khan H B, Islam M A \& Khadem A "Corporate sustainability reporting of major commercial banks in line with GRI: Bangladesh evidence" Accepted for presentation in the 6th Asia Pacific Interdisciplinary Research on Accounting (APIRA) Conference, to be held in the University of Sydney on 12-13July 2010, Sydney, Australia.

[13] Bala S.K and Bhowmik R.K, Statutory Amendments to the Income Tax Laws to effect the fiscal changes proposed through the national budget 2010-2011: A review, The Cost \& Management, Vol. xxxviii, no. 4, July-August 2010, Pp. 5-14

[14] Bhowmik R.K \& Bala S.K, Income Tax in National Budget 2011-12 and Salient Features of the Income Tax Portion of the Finance Act 2011, The Cost \& Management, no. 4, May-June 2011, Pp. 5-16

[15] Imam S, "Corporate social performance reporting in Bangladesh", Managerial Auditing Journal, vol. 15, 2000, Pp. 133-141

[16] Sultana N, "Corporate Social Responsibility in Bangladesh: Barriers and Opportunities experienced by SMEs when undertaking CSR" The Business and Economic Review, August, Vol. 01, No.3, 2009, Pp. 165-180

[17] Almona C. P, "A Review of the business case for Corporate Social Responsibility in the UK financial service sector", unpublished dissertation, 2005, Pp.1-94

[18] Jamali D and Mishak R., "Corporate social responsibility (CSR): Theory and practice in a developing country context" Journal of Business Ethics, vol. 72, 2007, Pp. 362.

[19] Kabir E 2003, "Corporate social responsibility in Bangladesh", The Financial Express of Bangladesh, viewed on 4 February, 2009, http://www.scribd.com/doc/3503656/Ekram-Kabirs-articles-on-Corporate-Social-Responsibility-in-Bangladesh

[20] Khan M.H.U.Z, Halabi A and Samy M., "CSR Reporting Practice: A study of Selected Banking Companies in Bangladesh", Social Responsibility Journal, Vol.5 No.3, 2009, Pp.344-357.

[21] Khan, M.H.U.Z., "The Effect of Corporate Governance elements on Corporate Social Responsibility (CSR) Reporting: Empirical Evidence from Private Commercial Banks of Bangladesh", International Journal of Law and Management, Vol. 52 No. 2, 2010, Pp.82-109.

[22] Quazi A, and O’Brien D, “An empirical test of a cross-national model of corporate social responsibility” Journal of Business Ethics vol. 25, 2000, Pp. 33- 51 